\title{
Problematika Pendidikan Anak Jalanan (Studi Anak Penjual Koran di Kota Kupang)
}

\author{
Syahrul $^{1}$, Mariatul Kibtiyah ${ }^{2}$ \\ Pendidikan Sosiologi, Fakultas Keguruan dan Ilmu Pendidikan, Universitas Muhammadiyah Kupang ${ }^{1,2}$ \\ E-mail: syahrul@unmuhkupang.ac.id ${ }^{1}$ mariatulkibtiyah1998@ gmail.com ${ }^{2}$
}

\begin{abstract}
Abstrak
Penelitian ini bertujuan untuk mengetahui faktor-faktor yang melatarbelakangi adanya anak penjual koran di Kota Kupang, dan mengetahui bagaimana pendidikan anak penjual koran di Kota Kupang. Metode yang digunakan dalam penelitian ini adalah kualitatif. Subjek penelitian adalah anak penjual koran di Kota Kupang. Data penelitian dikumpulkan melalui observasi, wawancara, catatan lapangan dan dokumentasi. Data penelitian ini dianalisis menggunakan teknik analisis kualitatif deskriptif yang terdiri dari koleksi data, reduksi data, penyajian data dan penarikan kesimpulan. Hasil penelitian ini menunjukan bahwa, (1) ada beberapa faktor yang melatarbelakangi munculnya anak penjual koran di Kota Kupang diantaranya adalah faktor ekonomi orangtua, faktor rendahnya pendidikan orangtua, faktor budaya masyarakat Timor, dan kemauan dari anak itu sendiri. (2) Pendidikan anak penjual koran di Kota Kupang terdiri dari dua jenis yaitu anak penjual koran yang masih sekolah dan anak penjual koran yang tidak sekolah. Anak penjual koran yang masih sekolah beranggapan bahwa pekerjaan sebagai penjual koran bukanlah menjadi penghalang bagi mereka untuk menempuh pendidikan, sedangkan anak penjual koran yang tidak sekolah dikarenakan faktor ekonomi yang tidak mendukung dan keegoisan orangtua.
\end{abstract}

Kata kunci: problematika pendidikan, anak penjual koran

\begin{abstract}
This study aims to know the factors behind the existence of newspaper sellers and to know how the education of newspaper sellers in Kupang City. The approach used in this research was qualitative. The subject of the research was the children's newspaper seller in Kupang City. Research data were collected through observation, interviews, field notes and documentation. The data was analyzed using descriptive qualitative analysis techniques consisting of data collection, data reduction, data presentation and concluding. The results of this study indicate that (1) several factors are underlying the emergence of children's newspaper sellers in Kupang City including the parents' economic factors, low parental education factors, cultural factors of the Timorese people, and the will of the children themselves. (2) The education of children selling newspapers in Kupang City consists of two types, namely children selling newspapers who are still in school and children selling newspapers who are not going to school. The children of newspaper sellers who are still in school assume that the job as a newspaper seller is not an obstacle for them to pursue education, while the children of newspaper sellers who do not go to school due to economic factors that do not support and the selfishness of parents.
\end{abstract}

Keywords: education, children of newspaper sellers

Copyright (c) 2020 Syahrul, Mariatul Kibtiyah

$\triangle$ Corresponding author

Address : Kota Kupang

Email : syahrul@unmuhkupang.ac.id

ISSN 2580-3735 (Media Cetak)

Phone :082337060959

ISSN 2580-1147 (Media Online)

DOI: https://doi.org/10.31004/basicedu.v4i4.531 
1337 Problematika Pendidikan Anak Jalanan (Studi Anak Penjual Koran di Kota Kupang) - Syahrul, Mariatul Kibtiyah

DOI: https://doi.org/10.31004/basicedu.v4i4.531

\section{PENDAHULUAN}

Bagian anak penjual koran di Kota Kupang cenderung disebabkan karena masalah ekonomi orangtua. Mereka ditempatkan pada kondisi tidak memiliki masa depan yang jelas karena keberadaan mereka menjadi masalah bagi banyak pihak di Kota Kupang. Fenomena merebaknya anak penjual koran di Kota Kupang adalah persoalan sosial yang sangat kompleks karena anak penjual koran bekerja sambil bersekolah, sehingga cenderung mudah putus sekolah. Selain itu, mereka menjadi salah satu penyangga ekonomi keluarga. Keterlibatan anak-anak di jalanan sebagai penjual koran menghambat masa depan mereka karena mereka terpaksa bekerja dan tidak peduli lagi dengan pendidikannya. Fenomena anak penjual koran di Kota Kupang sebetulnya sudah berkembang lama, tetapi saat ini semakin manjadi perhatian Pemerintah Kota Kupang, seiring dengan meningkatnya jumlah anak penjual koran yang putus sekolah setiap tahunnya (Mas'ud, 2019; Syahrul \& Datuk, 2018).

Anak penjual koran di Kota Kupang dipandang negatif oleh sebagian besar masyarakat karena ini sering dihubungkan sebagai salah satu penyebab munculnya anak putus sekolah. Penghasilan orangtua yang rendah menyebabkan anak sering dipekerjakan oleh orangtuanya sebagai penjual koran. Bahkan dalam kasus tertentu ada anak penjual koran yang harus bekerja karena sudah menjadi tulang punggung keluarga. Tempat tinggal anak penjual koran di Kota Kupang biasanya di taman kota, emperan toko, dan ada juga yang tinggal di rumah. Dampak adanya anak penjual koran adalah menjadi salah satu masalah sosial dalam masyarakat, masa depan yang makin suram, dan semakin bertambahnya angka anak yang putus sekolah di Kota Kupang. Kebanyakan anak penjual koran di Kota Kupang mengikuti jejak orangtunya yang memang sudah menjadi penjual koran dan hidup di jalan. Oleh karena itu, bagi mereka jalanan berfungsi sebagai tempat mencari nafkah dan juga berfungsi sebagai tempat tinggal (Hidayat, Anwar, \& Hidayah, 2017).

Anak penjual koran memiliki dua kategori, yaitu: pertama, anak penjual koran yang punya komunitas adalah mereka yang masih memiliki orangtua dan tempat tinggal yang jelas meski di pinggir-pinggir gang sebagai kaum urban dan sebagian besar masih sekolah. Kedua, anak penjual koran tidak memiliki keluarga adalah mereka yang sudah putus hubungan dengan orangtuanya dan anggota keluarga lain serta selama 24 jam hidup dan bekerja di jalanan dan sudah tidak sekolah. Kondisi di jalanan tidak hanya untuk menghasilkan pendapatan atau bergaul, tetapi juga membahayakan bagi keselamatan mereka. Faktor ekonomi orangtua yang menjadikan anak bekerja di usia dini sehingga mereka menghabiskan waktunya di jalanan demi mendapatkan penghasilan yang tak seberapa. Keegoisan orangtua juga bisa menjadikan anak turun kejalanan seperti tidak peduli dengan pendidikan anak, perkembangan anak, dan anak seakan-akan dijadikan alat untuk memperoleh penghasilan (Tjahjorini, Slamet, Asngari, \& Susanto, 2005).

Anak-anak penjual koran di Kota Kupang cenderung mudah putus sekolah secara dini karena mereka menjadi salah satu penyangga ekonomi keluarga. Mereka kebanyakan berasal dari 
1338 Problematika Pendidikan Anak Jalanan (Studi Anak Penjual Koran di Kota Kupang) - Syahrul, Mariatul Kibtiyah

DOI: https://doi.org/10.31004/basicedu.v4i4.531

keluarga kurang mampu sehingga orangtua mereka tidak mampu memenuhi kebutuhan ekonomi, pendidikan, kesehatan dan berbagai persoalan lain. Kebanyakan orantua mereka juga berasal dari keluarga yang kurang mampu sehingga pendidikan formal terabaikan karena faktor kemiskinan, sehingga inilah yang diwariskan pada anak-anak mereka juga. Anak-anak yang bekerja sebagai penjual koran umumnya berada dalam keadaan rentan terhadap perlakuan salah, bekerja pada kondisi jam kerja yang panjang, mendapatkan upah yang rendah, menghadapi resiko kecelakaan lalu lintas, gangguan kesehatan, menghambat tumbuh kembang mereka, mempengaruhi kondisi sosial anak, menjadi sasaran kejahatan seksual, serta dieksploitasi oleh orang dewasa (Puruhita, Suyahmo, \& Atmaja, 2016; Setiawan, 2017; Syahrul \& Wardana, 2017).

Persoalan di atas yang terjadi dalam pendidikan anak penjual koran, sehingga mereka lebih memilih menjadi anak penjual koran karena minimnya biaya pendidikan dari orangtua. Disisi lain, juga ada alasan khusus sehingga meraka lebih memilih untuk turun kejalan, di antaranya (1) keinginan dari diri sendiri untuk mencari uang tambahan, (2) keegoisan orangtua, dan (3) ajakan dari teman sebaya (Kurniaji, Yuniawan, \& Syaifudin, 2018; Prasetya \& Yoserizal, 2016; Puruhita et al., 2016). Banyak anak penjual koran yang berkegiatan di jalan dan menggunakan jalan untuk tempat tinggal dan hidup, berjualan, dan bermain. Menjadi anak penjual koran bukanlah pilihan hidup yang menyenangkan bagi anak-anak penjual koran di Kota Kupang, tetapi mereka terpaksa menjalani hidup sebagai penjual koran karena hal tertentu. Anak jalanan di Kota Kupang belum cukup mental menghadapi kehidupan yang keras, mereka yang seharusnya menikmati masa anak-anaknya harus menanggung beban hidup karena kurangnya faktor ekonomi orangtua. Padahal tidak dapat dipungkiri mereka adalah generasi penurus bangsa khususnya di NTT.

Penelitian sebelumnya yang dilakukan oleh Kushartati tentang pemberdayaan anak jalanan, menunjukan bahwa faktor-faktor yang sering kali dialami oleh anak penjual koran adalah akibat dari kondisi kemiskinan atau ada relasi yang lain mempengaruhi anak tersebut, yaitu kekerasan dalam keluarga, dorongan keluarga, impian kebebasan, ingin memiliki uang sendiri, dan pengaruh teman (Kushartati, 2004). Anak akan melakukan pemberontakan pada dirinya sendiri jika anak tersebut sering ditekan oleh orangtuanya ataupun lingkungan sekitar. Sehingga anak akan mencari jalan keluar dengan masalah tersebut misalnya, mereka beranggapan bahwa dengan hidup dijalanan akan mendapatkan kebebasan, tetapi justru sebaliknya masalah tidak berkurang akan tetapi memunculkan masalah baru (Syahrul, 2018, 2019).

Ajisuksmo mengatakan bahwa tidak hanya faktor ekonomi saja yang menjadikan anak menjadi penjual koran, tetapi ada juga berbagai masalah, misalnya, ketiadaan uang, keadaan rumah yang sempit dan tidak memenuhi standar kebutuhan, dan lain-lain. Di sisi lain kemiskinan keluarga yang mempengaruhi tumbuh kembang anak, yaitu kesehatan dan gizi, pola interaksi orangtua dengan anak, aspirasi orangtua terhadap masa depan anak, dukungan dan bentuk afeksi 
1339 Problematika Pendidikan Anak Jalanan (Studi Anak Penjual Koran di Kota Kupang) - Syahrul, Mariatul Kibtiyah

DOI: https://doi.org/10.31004/basicedu.v4i4.531

yang diberikan orangtua, kekerasan yang dialami anak, pola asuh, dan sebagainya (Ajisuksmo, 2013b). Sementara itu, hasil penelitian Pamuchtia dan Pandjaitan menunjukan bahwa anak jalanan di Kota Bogor disebabkan karena kesulitan dalam hal ekonomi dan sebagian lagi untuk mencari uang tambahan. Pendidikan orangtua anak penjual koran rata-rata tamatan Sekolah Dasar dan bekerja di sektor marjinal seperti buruh dan pada bidang jasa ojek dan membuka bengkel. Adapun sikap positif yang diperlihatkan oleh anak penjual koran di Kota Bogor, yaitu usaha mereka untuk memperbaiki diri dalam memilih pekerjaan dan berhubungan dengan orang lain yang tidak bekerja sebagai penjual koran ataupun orang lain yang tidak senasib dengan mereka (Pamuchtia \& Pandjaitan, 2010).

Saat ini, anak penjual koran di Kota Kupang menjadi perhatian Pemerintah Daerah NTT, seiring dengan meningkatnya jumlah anak penjual koran di Kota Kupang. Oleh karena itu, penelitian ini dilakukan dengan tujuan untuk mengetahui bagaimana pendidikan anak penjual koran di Kota Kupang. Sementara itu, beberapa penelitian telah menunjukan bahwa pemerintah maupun lembagalembaga sosial dan pendidikan dalam hal ini Kementrian Pendidikan dan Kebudayaan beserta Kementrian Sosial telah melakukan berbagai upaya untuk menanggulangi masalah anak penjual koran dengan melibatkan instansi yang terkait. Salah satu program kebijakan pendidikan anak anak penjual koran adalah pendidikan kegiatan berbasis masyarakat (PKBM). PKBM adalah suatu institusi yang berbasis masyarakat (Community Based Institution) (Mas'ud, 2019; Syahrul \& Datuk, 2018; Syahrul \& Wardana, 2017). Oleh karena itu, penelitian ini telah mendeskripsikan problematika pendidikan anak penjual koran serta faktor-faktor yang melatar belakangi munculnya anak penjual koran di Kota Kupang.

\section{METODE}

Penelitian ini merupakan penelitian kualitatif deskriptif untuk pemahaman lebih luas dan mendalam tentang kehidupan dan pendidikan anak penjual koran di Kota Kupang. Lokasi penelitian ini bertempat di Lampu Merah El Tari Kota Kupang Provinsi Nusa Tenggara Timur dikarenakan di tempat ini terdapat banyak anak penjual koran. Subjek penelitian ini adalah anak penjual koran di Kota Kupang. Pemilihan subjek penelitian ini adalah dengan teknik purposive sampling, yaitu subjek anak penjual koran dilihat dari aktivitas dan kesehariannya menjual koran di jalan dari pagi sampai malam.

Pengumpulan data dengan observasi dilakukan untuk mengamati aktivitas kehidupan dan pekerja anak penjual koran. Wawancara dilakukan terhadap informan kunci yaitu anak penjual koran untuk menggali informasi sebanyak mungkin sekaligus memberikan ruang yang seluasnya kepada informan untuk menceritakan apa dialaminya. Selanjutnya wawancara mendalam juga dilakukan untuk mendapatkan pola penanganan masalah pendidikan anak penjual koran. Catatan lapangan merupakan catatan tertulis mengenai apa yang didengar, dilihat, dialami dan dipikirkan dalam rangka mengumpulkan data dan refeleksi terhadap anak penjual koran.

Analisis data terdiri dari tiga alur kegiatan yang terjadi secara bersamaan, yaitu reduksi data, 
1340 Problematika Pendidikan Anak Jalanan (Studi Anak Penjual Koran di Kota Kupang) - Syahrul, Mariatul Kibtiyah

DOI: https://doi.org/10.31004/basicedu.v4i4.531

penyajian data dan penarikan kesimpulan. Reduksi data bertujuan untuk merangkum, memilih dan memfokuskan hal-hal penting yang berkaitan dengan permasalahaan pekerja dan pendidikan anak penjual koran. Dengan demikian, data yang telah direduksi akan memberikan gambaran yang lebih jelas dan mempermudah peneliti untuk melakukan penyajian data. Selanjutnya data-data tersebut akan disajikan dalam bentuk uraian singkat, bagan, hubungan antar kategori, dan sejenisnya demi memudahkan pemahaman tentang apa yang terjadi dan dipahami dari gambaran diri subjek anak penjual koran. Kemudian melalui proses penyajian data tersebut peneliti menarik kesimpulan dari masalah pekerjaan dan pendidikan anak penjual koran di Kota Kupang.

\section{HASIL DAN PEMBAHASAN}

Latar Belakang Anak menjadi Penjual Koran di Kota Kupang

Pada umumnya anak menjadi penjual koran di Kota Kupang karena kebutuhan dan hak anak tidak terpenuhi dengan baik. Hal ini menjadikan anak penjual koran di Kota Kupang mencari hidup di Jln. El-Tari. Tanpa adanya pertimbangan dari orangtua bahwa kondisi di jalanan sangat membahayakan keselamatan bagi anak jika mereka harus berjualan koran di lampu merah. Namun karena faktor kemiskinan, orangtua memaksa anaknya bekerja di jalanan sebagai penjual koran, sehingga mereka menghabiskan waktu luang untuk mencari uang tambahan untuk memenuhi kebutuhan keluarga. Ini juga disebabkan karena keegoisan orangtua yang memaksa anaknya bekerja demi membantu orantuanya untuk mencukupi kebutuhan hidup tanpa memperhatikan pendidikan anak, sehingga anak seolah-olah menjadi alat untuk menghasilkan uang.

Masih banyaknya masyarakat Timor di bawah garis kemiskinan membuat anak sangatlah rentan menjadi penjual koran akibat desakan dari orangtua. Anak merasa tertekan dirumah karena setiap hari mendengarkan keluhan orangtua, pada akhirnya anak memilih ikut orangtua untuk berjualan koran di Jln. El-Tari Kota Kupang. Tekanan kemiskinan adalah kondisi yang memaksakan anak-anak menjadi penjual koran di Kota Kupang. Kebanyakan anak-anak berjualan koran di jalanan dan toko-toko. Anak berjualan koran bukanlah atas kemauan sendiri, tetapi kebanyakan dipaksa oleh orangtuanya. Meskipun sudah ada usaha Pemerintah untuk meningkatkan pendidikan di NTT, tetapi kenyataannya masih banyak anak penjual koran yang tidak bersekolah dikarenakan faktor kemiskinan.

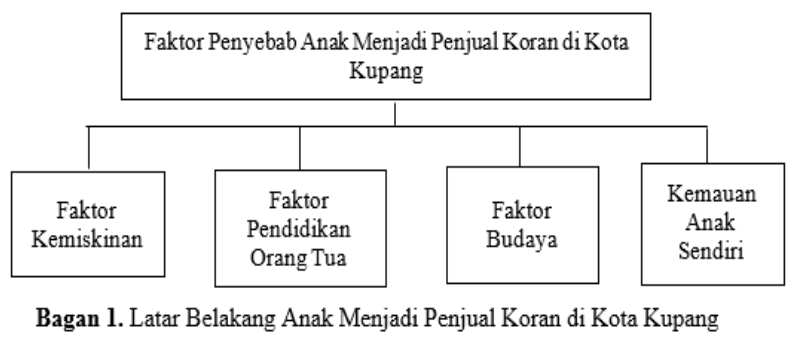

Berdasarkan Bagan 1, latar belakang anak menjadi penjual koran di Kota Kupang karena masalah kemiskinan, rendahnya pendidikan orangtua, budaya masyarakat Timor dan kemauan anak sendiri. Mereka ditempatkan pada kondisi tidak memiliki masa depan yang jelas. Keberadaan mereka tak jarang jadi masalah banyak pihak, baik keluarga, masyarakat bahkan Pemerintah Kota 
1341 Problematika Pendidikan Anak Jalanan (Studi Anak Penjual Koran di Kota Kupang) - Syahrul, Mariatul Kibtiyah

DOI: https://doi.org/10.31004/basicedu.v4i4.531

Kupang. Lebih jauh lagi, latar belakang munculnya anak penjual koran di Kota Kupang akan diuraikan pada beberapa poin berikut.

\section{Faktor Kemiskinan Sehingga Anak Menjadi Penjual Koran}

Berdasarkan hasil observasi, ditemui berbagai macam anak penjual koran pada siang hari di Jl. El-Tari Kota Kupang dengan tujuan untuk membantu orangtua. Dalam observasi ini, peneliti menemukan dua alasan mengapa anakanak tersebut menjadi penjual koran, yaitu (1) anak membantu orangtuanya menjual koran karena pengahasilan orangtua mereka tidak mencukupi untuk memenuhi kebutuhan hidup keluarga, dan (2) membantu orangtunya yang sedang sakit. Melihat dua alasan tersebut, kemiskinan orangtua merupakan salah satu faktor utama yang memicu anak-anak untuk bekerja sebagai penjual koran di Kota Kupang. Hal ini diperjelas dalam wawancara dengan anak penjual koran yang mengungkapkan bahwa,

saya sudah bekerja sebagai penjual koran sejak kecil karena waktu saya ikut bersama ayah yang juga sebagai seorang loper koran. Meskipun sekarang saya masih sekolah akan tetapi saya menggunakan waktu setelah pulang sekolah untuk berjualan koran karena kehidupan ekonomi keluarga yang pas-pasan sehingga saya tidak mempunyai pilihan lain untuk membantu orangtua selain berjualan koran. Orangtua mengetahui apa yang saya kerjakan dan mereka selalu berpesan untuk tetap berhati-hati. Pendapatan saya selama berjualan tidak menentu apalagi sekarang lagi dilanda bencana pandemi corona. Uang yang saya dapatkan separuh saya berikan kepada orangtua dan separuhnya saya tabung (Nomleni, 2020).
Sementara itu, anak penjual koran lainnya yang ditemui pada malam hari juga mengatakan hal yang sama bahwa,

orangtua saya tau kalau saya berjualan koran, dan orangtua saya tidak mempersoalkan saya berjualan koran yang terpenting tetap rajin sekolah. Uang dari hasil jualan koran saya gunakan untuk keperluan sekolah seperti membeli buku dan bolpoin dan sisanya untuk jajan. Alasan saya berjualan koran agar punya penghasilan sendiri dan mengisi waktu kosong disaat sepulang sekolah (Sara, 2020).

Berdasarkan hasil wawancara di atas, diketahui bahwa faktor kemiskinan pada akhirnya membuat orangtua tidak bisa melarang anaknya untuk bekerja sebagai penjual koran di Kota Kupang. Tanpa disadari orangtua justru merasa senang dan terbantu oleh pekerjaan anaknya tersebut karena dapat membantu meringankan beban keluarga. Faktor kemiskinan menjadi salah satu faktor yang sangat mempengaruhi keberadaan anak penjual koran di Kota Kupang. Dari faktor kemiskinan tersebut ditemukan masalah yang ada di dalamnya antara lain mengenai jumlah pendapatan dan penghasilan. Hal ini dapat dilihat dari dua sisi, yaitu dari sisi pendapatan orangtua yang pas-pasan bahkan terkadang tidak cukup untuk memenuhi kebutuhan sehari-hari. Sedangkan dari sisi pendapatan anak, jumlahnya tergantung pekerjaan yang mereka lakukan di jalan, sebagian besar penghasilan yang mereka peroleh diberikan kepada orangtua dan sebagian kecilnya digunakan untuk memenuhi kebutuhan mereka seperti uang jajan, keperluan sekolah dan lain-lain. 
1342 Problematika Pendidikan Anak Jalanan (Studi Anak Penjual Koran di Kota Kupang) - Syahrul, Mariatul Kibtiyah

DOI: https://doi.org/10.31004/basicedu.v4i4.531

Faktor Pendidikan Orangtua sehingga Anak Menjadi Penjual Koran

Pendidikan orangtua yang rendah menjadi salah satu penyebab munculnya anak penjual koran di Kota Kupang. Ternyata tingkat pendidikan orangtua anak penjual koran di Kota Kupang tersebut sangat rendah, ada yang hanya lulusan Sekolah Dasar (SD) dan sebagian lainnya hanya lulus Sekolah Menengah Atas (SMA) bahkan ada juga orangtua yang tidak sekolah. Rendahnya pendidikan orangtua anak tersebut pada akhirnya berimbas pada pekerjaan orangtua anak itu sendiri yang tidak dapat bersaing dengan warga pendatang lain yang tingkat pendidikannya lebih tinggi, dan didukung lagi dengan kemampuan dan keahlian lain yang telah dimiliki oleh mereka yang telah siap mengadu nasib di Kota Kupang sebagai pendatang. Hasil wawancara dengan orangtua anak penjual korang mengatakan bahwa,

saya mengetahui pekerjaan anak saya karena saya yang menyuruhnya untuk berjualan koran. Saya mendukung bahkan selalu mengingatkan kepada anak saya ketika mulai malas berjualan. Hasil dari jualan koran sepenuhnya diserahkan kepada saya untuk kebutuhan sehari-hari (Tefa, 2020).

Selain itu, ditemukan orangtua anak penjual koran yang juga mengungkapkan hal yang sama bahwa,

saya mengetahui karena saya yang meminta dia untuk berjualan koran bahkan ketika dia tidak berjualan, saya memarahinya. Uang yang dia dapatkan langsung diserahkan pada saya (Henuk, 2020).

Hasil wawancara di atas menunjukan bahwa orangtua anak penjual koran tidak mengutamakan pendidikan. Padahal salah satu kebutuhan yang mendasar bagi anak adalah pendidikan, maka bagaimanapun caranya orangtua harus tetap mengupayakan agar anaknya mendapatkan pendidikan yang layak meskipun orangtuanya tidak berpendidikan formal. Pendidikan merupakan landasan utama guna mewujudkan segala keinginan dan cita-cita anak penjual koran. Mengubah kehidupan masa depan menjadi lebih baik adalah keinginan dari anak-anak penjual koran di Kota Kupang tersebut. Selain itu akibat dari tingkat pendidikan orangtua yang rendah mengakibatkan tumbuh kembang anak ikut terpengaruh, mereka kurang begitu semangat dalam hal menempuh pendidikan dikarenakan orangtuanya tidak bisa mengarahkan anaknya, yang terpenting si anak bisa menulis itu sudah dianggap cukup, untuk selanjutnya terserah keinginan mereka. Data yang diperoleh dari lapangan menunjukkan bahwa ada 4 orang anak yang bersekolah di tingkat Sekolah Dasar (SD), 4 orang anak sekolah di Sekolah Menegah Pertama (SMP), 2 orang anak sekolah di Sekolah Menengah Atas (SMA) dan 1 orang anak lainnya sudah putus sekolah.

Penyebab anak menjadi penjual koran di Kota Kupang karena latar belakang pendidikan orangtua yang rendah. Di sisi lain, keluarga merupakan sekolah pertama bagi anak baik secara mental dan kepribadian, bahkan keluarga merupakan tempat pertama bagi anak-anak dalam memperoleh hak dasar mereka sebagai anak. Peran didikan orangtua dalam kelaurga adalah menentukan seorang anak bisa bekerja atau tidak karena orangtua adalah orang pertama yang 
1343 Problematika Pendidikan Anak Jalanan (Studi Anak Penjual Koran di Kota Kupang) - Syahrul, Mariatul Kibtiyah

DOI: https://doi.org/10.31004/basicedu.v4i4.531

berhubungan langsung dengan anak. Lingkungan keluarga adalah lingkungan yang pertama kali dikenal oleh anak, sehingga anak mulai menerima nilai-nilai baru dalam keluarga dan dari kelurga tersebut anak pun ikut mensosialisaikan diri. Oleh karena itu, tingkat pendidikan orangtua sangat dibutuhkan dalam mendidikan anak dalam keluarga.

Faktor Budaya Masyarakat Timor Sehingga Anak Menjadi Penjual Koran

Anak yang mengikuti orangtua bekerja untuk membantu keluarganya mencari nafkah dinilai sebagai rasa empati seorang anak terhadap orangtua. Mereka mengganggap bahwa semakin besar pengorbanan untuk orangtua maka semakin besar pahala yang mereka dapatkan. Berpikir kembali tentang pahala sehingga menyebabkan timbulnya dorongan anak yang dengan sendirinya dan ikhlas melakukan pekerjaan tersebut dengan senang hati karena mereka mau dikatakan anak yang rajin dan berbakti kepada orangtua (Syahrul, 2020). Hal ini diperkuat dari hasil wawancara dengan anak penjual koran yang mengatakan bahwa,

saya berjualan koran karena tidak ingin membebani orangtua. Orangtua mengetahui akan pekerjaan saya. Orangtua sempat melarang saya untuk berjualan koran tetapi saya tetap berjualaan karena sangat membantu untuk keperluan sekolah. Saya juga ingin menjadi anak yang berbakti pada orangtua (Foeh, 2020).

Karena tidak ingin membebani orangtua, saya berjualan koran. Hasil dari jualan koran saya gunakan untuk membeli jajan. Orangtua mengetahui tentang pekerjaan saya dan mereka sangat mendukung (Embe, 2020).
Karena tidak ingin membebani orangtua, saya berjualan koran untuk jajan kadang juga buat isi pulsa. Pendapatan saya tidak pasti, apalagi sekarang adanya wabah COVID-19 pendaptan semakin menurun. Orangtua saya mengetahui kalau saya berjualan koran namun mereka tetap mengizinkan asalkan saya harus hati-hati (Laba, 2020).

Hasil wawancara di atas menunjukkan bahwa ada penguruh budaya di dalamnya sehingga anak menjadi penjual koran, yaitu tradisi orang Timor secara turun-temurun yang membantu orangtua apabila dalam kesusahan dan anak harus berbakti kepada orangtua serta tidak boleh menyusahkan orangtua karena mereka percaya bahwa itu adalah dosa. Oleh karena itu, bekerja di jalanan sebagai penjual koran mereka lakukan atas unsur kebiasaan, paksaan, keinginan atau kesadaran individu masing-masing untuk membantu perekonomian keluarga minimal untuk mencukupi kebutuhan sehari-hari dan keinginan mereka. Meskipun dengan kondisi yang sangat memperihatinkan dan sebenarnya sulit sekali dijalani oleh anak-anak penjual koran, mereka tetap memiliki pekerjaan ini untuk melakukan usaha-usaha demi membantu orangtua mereka. Sehingga dengan kondisi seperti ini, justru terlihat tingkat kemandirian dan kemauan untuk usaha sangat menonjol pada diri anak penjual koran. Mereka tidak takut untuk berjualan dipinggir jalan atau sudut-sudut lampu merah. Semua itu mereka lakukan dengan senang hati.

\section{Kemauan Sendiri Anak Menjadi Penjual Koran}

Menjual koran di jalanan ataupun di tokotoko membuktikan anak-anak dapat memiliki 


\section{Problematika Pendidikan Anak Jalanan (Studi Anak Penjual Koran di Kota Kupang) - Syahrul, Mariatul Kibtiyah \\ DOI: https://doi.org/10.31004/basicedu.v4i4.531}

penghasilan sendiri dan bahkan memiliki otonomi untuk mengelola uang yang didapatkan secara mandiri. Meskipun uang tersebut tidak sepenuhnya digunakan oleh anak penjual koran karena sebagian uang tersebut diserahkan kepada orangtua, tetapi setidaknya mereka memiliki hak atas uang yang diperolehnya. Dengan melihat penghasilan yang mereka peroleh ini membuat kemauan anak untuk mendapatkan uang itu semakin tinggi. Hasil wawancara dengan anak penjual koran mengatakan bahwa,

orangtua mengetahui tentang pekerjaan saya. Orangtua sempat melarang saya untuk jualan koran, tapi saya tetap melakukan pekerjaan saya. Uang yang saya dapat, saya gunakan untuk memenuhi kebutuhan sekolah dan sebagiannya saya serahkan ke orangtua untuk membantu ekonomi keluarga (Putri, 2020).

Senada dengan hasil wawancara anak penjual koran lainnya yang mengatakan bahwa,

karena ingin mempunyai pendapatan, saya berusaha sendiri dengan berjualan koran. Pendapatan tergantung seberapa banyak koran yang laku dalam satu hari. Uang hasil jualan koran saya pake buat jajan seharihari. Meskipun orangtua mengetahui tentang pekerjaan saya, mereka tidak mempersoalkan apa yang saya kerja selama ini (Masu, 2020).

Lebih jauh lagi, ditemui juga anak penjual koran yang mengatakan bahwa,

orangtua saya tahu kalau saya berjualan koran, orangtua saya juga tidak mempersoalkan saya berjualan koran, dan uang hasil berjualan saya gunakan untuk isi pulsa data, jajan, dan keperluan lain. Saya bekerja jualan koran hanya untuk mengisi waktu luang saja (Apriani, 2020).
Hasil wawancara di atas menunjukkan bahwa anak penjual koran lebih memilih memanfaatkan waktu luang mereka dengan menjual koran di Jln. El-Tari Kota kupang. Hasil wawancara di atas juga dapat dimaknai bahwa anak penjual koran tersebut bekerja bukan hanya sekedar membantu orangtua, tetapi kemauan sendiri. Mereka berpikir bahwa dengan menjual koran mereka langsung mendapatkan hasilnya dengan segera, dan bisa menambah uang jajan di sekolah. Pekerjaan menjual koran menjadi hal sangat bermanfaat bagi mereka karena didukung juga oleh orangtua, dan mereka bisa menghasilkan pendapatan secara mandiri walaupun akan dibagi dengan orangtua. Apa yang mereka kerjakan ini juga karena berpikir berbakti kepada orangtua, dan ingin dikatakan sebagai anak yang baik sehingga melakukan pekerjaan ini sangat mereka nikmati.

\section{Pendidikan Anak Penjual Koran di Kota Kupang}

Anak penjual koran di Kota Kupang yang terlahir dari keluarga kurang mampu pasti akan mengalami kesulitan untuk mendapatkan pendidikan karena mereka tidak mempunyai uang untuk biaya pendidikan. Masalah pendidikan anak penjual koran di Kota Kupang sudah menjadi perhatian khusus bagi pemerintah Kota Kupang. Hasil observasi menunjukkan bahwa anak penjual koran di Kota Kupang rata-rata masih sekolah pada tingkat dasar/SD, dan sebagian lagi putus sekolah pada jenjang tingkat dasar. Oleh karena itu, sebagian besar anak usia sekolah yang berjualan koran di lampu merah El-tari Kota Kupang adalah pada tingkat Sekolah Dasar (SD). 
1345 Problematika Pendidikan Anak Jalanan (Studi Anak Penjual Koran di Kota Kupang) - Syahrul, Mariatul Kibtiyah

DOI: https://doi.org/10.31004/basicedu.v4i4.531

Selain itu, banyaknya anak penjual koran di Kota Kupang dikarenakan banyaknya biaya yang harus dikeluarkan untuk kepentingan pendidikan dan menambah uang saku. Mereka juga telah berpikir untuk menghasilkan uang sendiri dan tidak menyusahkan kedua orangtuanya.

Pendidikan adalah hak setiap warga negara, namun bila kita melihat realitas hari ini di Kota Kupang atau NTT secara keseluruhan, belum layak dikatakan pendidikan sebagai hak setiap warga Negara karena masih banyak anak-anak di yang tidak dapat mengenyam pendidikan formal. Dari beberapa anak penjual koran di Kota Kupang yang peneliti wawancarai sudah menjadi contoh kecil bahwa masih banyak anak-anak bangsa yang tidak dapat melanjutkan pendidikan sebagaimana harapan kita bersama. Pendidikan merupakan kebutuhan yang paling utama selain sandang dan pangan. Pendidikan merupakan kebutuhan yang sangat penting untuk mewujudkan masa depan dan cita-cita yang lebih baik bagi anak karena mengubah masa depan yang lebih baik adalah keinginan setiap anak penjual koran di Kota Kupang. Hal utama yang dihadapi oleh anak penjual koran dalam proses pendidikan adalah kemampuan biaya pendidikan yang minim, sehingga anak terpaksa ikut serta dalam mencari biaya hidup dan pendidikan di jalanan.

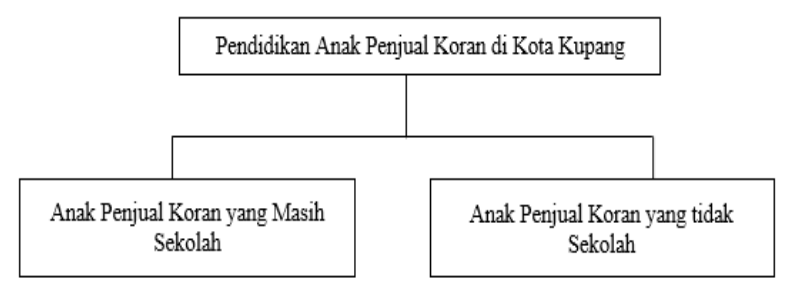

Bagan 2. Pendidikan Anak Penjual Koran di Kota Kupang

\section{Anak Penjual Koran yang Masih Sekolah}

Anak penjual koran yang masih mempunyai kesadaran akan pentingnya pendidikan masih tetap mengikuti pendidikan sesuai dengan jadwal sekolah. Mereka masih menganggap bahwa pendidikan akan membuat hidup mereka dan keluarga berubah ke depannya walaupun sedikit demi sedikit. Beberapa anak penjual koran di Kota Kupang menganggap bahwa dengan menempuh pendidikan dapat membantu beban orangtua dimasa yang akan datang. Meskipun kondisi mereka harus berjualan koran sambil sekolah, akan tetapi masalah masa depan tidak pernah luput dari pikirannya. Pendidikan mereka ini didukung penuh oleh orangtua, meskipun mereka dari keluarga miskin. Anak menjadi penjual koran tidak menjadi penghalang bagi orangtua untuk tidak mendorong mereka dalam menempuh pendidikan. Orangtua berpikir bahwa mendorong anak untuk menempuh pendidikan agar tidak bernasib sama dengan orangtuanya. Seperti yang disampaikan oleh anak penjual koran yang mengatakan bahwa,

saya bersekolah karena melalui pendidikan saya bisa menggapai cita-cita yang saya harapkan. Kalau mau dibilang tidak terganggu tetapi kadang-kadang saya merasa terganggu saat sekolah, mau dibilang terganggu tetapi saya menikmati apa yang saya kerjakan sebagai penjual koran. Tanggapan kawan-kawan saya itu beragam ada yang mendukung ada yang tidak karena ada beberapa tugas yang tidak saya kerjakan. Tetapi bagi saya itu semua merupakan motivasi bagi saya untuk lebih bijak lagi membagi waktu antara kerja dan pendidikan. Guru rata-rata sudah mengetahui apa yang saya kerjakan sehingga mereka memotivasi saya untuk tetap semangat dalam sekolah meskipun 


\section{Problematika Pendidikan Anak Jalanan (Studi Anak Penjual Koran di Kota Kupang) - Syahrul, Mariatul Kibtiyah \\ DOI: https://doi.org/10.31004/basicedu.v4i4.531}

saya mempunyai pekerjaan sampingan sebagai penjual koran (Nomleni, 2020).

Lebih jauh lagi, salah satu anak penjual koran juga mengatakan bahwa,

Saya masih sekolah. Sekolah saya tidak terganggu tetapi saya harus membagi waktu. Kawan-kawan mendukung saya tapi kadang-kadang ada yang suka mengganggu saya sebagai seorang penjual koran. Guru di sekolah selalu mengingatkan kepada saya agar saya bisa membagi waktu antara sekolah dengan kerja. Karena guru mengetahui latar belakang keluarga saya sehingga ia memaklumi (Tefa, 2020).

Hasil wawancara diatas menunjukan bahwa pekerjaan sebagai penjual koran bukanlah menjadi penghalang bagi anak untuk menempuh pendidikan. Batas waktu mereka menjual koran mengikuti jam kerja mereka di jalanan. Seperti yang dikatakan oleh anak penjual koran bahwa kalau dikatakan mengganggu, tentunya menggangu, tetapi mereka nyaman dengan pekerjaan yang mereka lakukan. Prinsip dari anak penjual koran ini bahwa, pada intinya mereka tetap mengenyam pendidikan karena pendidikan bagi anak penjual koran di Kota Kupang merupakan suatu harapan keluarga. Selain itu, orangtuanya berpikir agar tidak mengalami nasib yang sama, paling tidak pekerjaan anaknya lebih baik dibandingkan dengan orangtuanya.

\section{Anak Penjual Koran yang Tidak Sekolah}

Data yang diperoleh menunjukan bahwa terdapat beberapa anak penjual koran yang tidak tamat pendidikan dasar karena faktor kemiskinan dan keegoisan orangtua. Selain itu, data ini juga menunjukan bahwa tingkat pendidikan orangtua juga sangat mempengaruhi anak agar tetap bersekolah sambil jual koran. Pendidikan orangtua yang rendah menjadi salah satu penyebab anak putus sekolah pada tingkat sekolah dasar. Perlakuan orangtua yang tingkat pendidikannya tinggi akan memberikan kesempatan, dukungan, dan fasilitas yang dibutuhkan anak untuk tetap sekolah. Sedangkan orangtua dengan pendidikan formalnya rendah dinilai tidak cukup menghargai pendidikan, memotivasi, dan mendukung anak di sekolah. Alasan ini sehingga ada anak penjual koran di Kota Kupang yang tidak sekolah dan putus sekolah. Seperti yang diungkapkan oleh anak penjual koran yang putus sekolah bahwa,

saya tidak sekolah karena kondisi keuangan orangtua, bahkan orangtua saya mengetahui karena mereka yang meminta saya berhenti sekolah untuk berjualan koran, dan orangtua mendukung bahkan ketika saya tidak berjualan mereka memarahi saya (Henuk, 2020).

Berdasarkan hasil wawacara di atas, ternyata ada banyak faktor yang mendasari problematika pendidikan anak penjual koran di Kota Kupang. Lebih jauh lagi, diperoleh juga data yang lebih problematika sehingga anak penjual koran tidak sekolah, yaitu orangtua yang tidak bersedia untuk membiayai pendidikan anaknya dan Dinas Sosial dan Dinas Pendidikan yang tidak kopratif dalam mendukung pendidikan anak penjual koran di Kota Kupang. Kedua aspek ini dapat dimaknai bahwa, persoalan sesungguhnya bukan terletak pada anak yang bersangkutan melainkan orangtua yang telah diamanahkan untuk mendidik anak, tetapi mereka justru mengabaikan dan mendukung anak-anaknya 
1347 Problematika Pendidikan Anak Jalanan (Studi Anak Penjual Koran di Kota Kupang) - Syahrul, Mariatul Kibtiyah

DOI: https://doi.org/10.31004/basicedu.v4i4.531

untuk berkerja mencari nafkah dengan alasan ekonomi keluarga yang serba kekurangan.

Bagaimanapun kondisi ekonomi orangtua, mereka tetap bertanggungjawab terhadap hak-hak anaknya terutama pendidikan karena anak sebagai penerus masa depan orangtuanya. Oleh karena itu, mereka membutuhkan pendidikan yang layak disertai dengan skill agar kedepannya anak dapat tumbuh dan berkembang sesuai dengan apa yang mereka cita-citakan. Sementara itu, Pemerintah Kota Kupang yang telah diamanahkan untuk menyelesaikan persoalan ini, namun data di lapangan menunjukkan bahwa, mereka belum maksimal dalam menjalankan tugas dan tanggungjawabnya. Buktinya masih banyak anak penjualan korang berkeliaran di Kota Kupang yang putus sekolah karena faktor kemiskinan. Mereka paling banyak di lampu merah Jln. Eltari di depan Kantor Gubernur NTT.

\section{SIMPULAN}

Penelitian ini menunjukkan bahwa ada beberapa faktor yang melatar belakangi munculnya anak penjual koran di Kota Kupang, diantaranya (1) faktor kemiskinan, yaitu anak terpaksa berjualan koran meskipun dengan usia yang belum cukup untuk bekerja karena orangtua tidak mampu memenuhi kebutuhan pendidikan dan kehidupan mereka sehari-hari. (2) Rendahnya pendidikan orangtua sekaligus menjadi penyebab rendahnya kesadaran orangtua terhadap pentingnya pendidikan, sehingga menyebabkan anak putus sekolah dan menjadi penjual koran di Kota Kupang. (3) Faktor budaya karena anak menganggap membantu orangtua adalah sebuah wujud bakti mereka terhadap orangtua. (4) Adanya kemauan anak untuk berjualan koran karena mereka dapat memperoleh uang daripada di sekolah. Pendidikan anak penjual koran di Kota Kupang terdiri dari dua jenis, yaitu, anak penjual koran yang masih sekolah dan anak penjual koran yang tidak sekolah. Anak penjual koran yang masih sekolah beranggapan bahwa pekerjaan sebagai penjual koran bukanlah menjadi penghalang bagi mereka untuk menempuh pendidikan, sedangkan anak penjual koran yang tidak sekolah dikarenakan faktor ekonomi orangtua yang tidak mendukung dan keegoisan orangtua sehingga mereka berjualan koran untuk membantu kebutuhan keluarga.

\section{DAFTAR PUSTAKA}

Ajisuksmo, C. R. P. (2013). Faktor-faktor Penting Dalam Merancang Program Pendidikan Luar Sekolah Untuk Anak Jalanan dan Pekerja Anak. Hubs-Asia, 10(1). Retrieved from

http://hubsasia.ui.ac.id/old/index.php/hubsas ia/article/view/1466

Apriani, M. (2020, March 1). Latar Belakang Munculnya Anak Penjual Koran di Kota Kupang dan Pendidikan Anak Penjual Koran di Kota Kupang (M. Kibtiyah, Interviewer).

Embe, F. (2020, March 2). Latar Belakang Munculnya Anak Penjual Koran di Kota Kupang dan Pendidikan Anak Penjual Koran di Kota Kupang (M. Kibtiyah, Interviewer).

Foeh, F. (2020, March 1). Latar Belakang Munculnya Anak Penjual Koran di Kota Kupang dan Pendidikan Anak Penjual Koran di Kota Kupang (M. Kibtiyah, Interviewer).

Henuk, S. (2020, March 1). Latar Belakang Munculnya Anak Penjual Koran di Kota Kupang dan Pendidikan Anak Penjual 
1348 Problematika Pendidikan Anak Jalanan (Studi Anak Penjual Koran di Kota Kupang) - Syahrul, Mariatul Kibtiyah

DOI: https://doi.org/10.31004/basicedu.v4i4.531

Koran di Kota Kupang (M. Kibtiyah, Interviewer).

Hidayat, M. A., Anwar, A., \& Hidayah, N. (2017). Pendidikan Non Formal Dalam Meningkatkan Keterampilan Anak Jalanan. EDUDEENA: Journal of Islamic Religious Education, l(1). https://doi.org/10.30762/ed.v1i1.445

Kurniaji, F., Yuniawan, T., \& Syaifudin, A. (2018). Pilihan Bahasa Anak Jalanan Penjual Koran di Kawasan Tugu Muda Semarang. Jurnal Sastra Indonesia, 7(2), 148-154. Retrieved from https://journal.unnes.ac.id/sju/index.php/jsi/ article/view/29837

Kushartati, S. (2004). Pemberdayaan Anak Jalanan. Humanitas: Jurnal Psikologi Indonesia, 1(2). Retrieved from https://www.neliti.com/publications/24530/p emberdayaan-anak-jalanan

Laba, A. (2020, March 3). Latar Belakang Munculnya Anak Penjual Koran di Kota Kupang dan Pendidikan Anak Penjual Koran di Kota Kupang.

Masu, M. (2020, February 29). Latar Belakang Munculnya Anak Penjual Koran di Kota Kupang dan Pendidikan Anak Penjual Koran di Kota Kupang (M. Kibtiyah, Interviewer).

Mas'ud, F. (2019). Implikasi Undang-Undang Perlindungan Anak terhadap Pekerja Anak (Suatu Kajian Sosiologi Hukum terhadap Anak Penjual Koran di Kota Kupang). JPK (Jurnal Pancasila Dan Kewarganegaraan), 4(2), 11-19. https://doi.org/10.24269/jpk.v4.n2.2019.pp1 1-19

Nomleni, L. (2020, March 4). Latar Belakang Munculnya Anak Penjual Koran di Kota Kupang dan Pendidikan Anak Penjual Koran di Kota Kupang (M. Kibtiyah, Interviewer).

Pamuchtia, Y., \& Pandjaitan, N. K. (2010). Konsep Diri Anak Jalanan: Kasus Anak Jalanan di Kota Bogor Provinsi Jawa Barat. Sodality: Jurnal Sosiologi Pedesaan, 4(2). https://doi.org/10.22500/sodality.v4i2.5844
Prasetya, O., \& Yoserizal, Y. (2016). Perilaku Sosial Anak Jalanan di Kawasan Simpang 4 Pasar Pagi Arengka (Journal:eArticle, Riau University). Riau University. Retrieved from https://www.neliti.comNone

Puruhita, A. A., Suyahmo, S., \& Atmaja, H. T. (2016). Perilaku Sosial Anak-Anak Jalanan di Kota Semarang. Journal of Educational Social Studies, 5(2), 104-112. Retrieved from

https://journal.unnes.ac.id/sju/index.php/jess /article/view/14073

Putri. (2020, February 29). Latar Belakang Munculnya Anak Penjual Koran di Kota Kupang dan Pendidikan Anak Penjual Koran di Kota Kupang (M. Kibtiyah, Interviewer).

Sara, M. (2020, March 4). Latar Belakang Munculnya Anak Penjual Koran di Kota Kupang dan Pendidikan Anak Penjual Koran di Kota Kupang (M. Kibtiyah, Interviewer).

Setiawan, H. H. (2017). Mencegah Menjadi Anak Jalanan dan Mengembalikannya Kepada Keluarga Melalui Model Community Based. Sosio Konsepsia, 12(2), 44-53. https://doi.org/10.33007/ska.v12i2.631

Syahrul, S. (2018). Kritik Ideologi Pendidikan Karakter dalam Masyarakat Demokrasi di Indonesia. Seminar Nasional Pendidikan Dan Kewarganegaraan IV, O(0), 58-67. Retrieved from http://seminar.umpo.ac.id/index.php/SEMN ASPPKN/article/view/158

Syahrul, S. (2019). Internalisasi Pendidikan Multikultural dan Inklusif pada Anak Pengungsi Internasional di Kota Makassar. JPK (Jurnal Pancasila dan Kewarganegaraan), 4(3), 25-34. https://doi.org/10.24269/jpk.v4.n3.2019.pp2 5-34

Syahrul, S. (2020). Menanamkan Kemuhammadiyaan Pada Mahasiswa NonMuslim Melalui Pendidikan Multikultural di Universitas Muhammadiyah Kupang. EDUKASI: Jurnal Penelitian Pendidikan Agama Dan Keagamaan, 18(2). https://doi.org/10.32729/edukasi.v18i2.643 
1349 Problematika Pendidikan Anak Jalanan (Studi Anak Penjual Koran di Kota Kupang) - Syahrul, Mariatul Kibtiyah

DOI: https://doi.org/10.31004/basicedu.v4i4.531

Syahrul, S., \& Datuk, A. (2018). Perilaku Sosial Anak Penjual Koran di Kota Kupang Dalam Mempertahankan Eksistensinya di Sekolah. DIMENSIA: Jurnal Kajian Sosiologi, 7(2), 68-82. Retrieved from https://journal.uny.ac.id/index.php/dimensia/ article/view/32651

Syahrul, S., \& Wardana, A. (2017). Analisis kebijakan pendidikan untuk anak jalanan di Kota Yogyakarta. Harmoni Sosial: Jurnal Pendidikan IPS, 4(2), 117-130. https://doi.org/10.21831/hsjpi.v4i2.10388

Tefa, M. (2020, March 4). Latar Belakang Munculnya Anak Penjual Koran di Kota Kupang dan Pendidikan Anak Penjual Koran di Kota Kupang (M. Kibtiyah, Interviewer).

Tjahjorini, S., Slamet, M., Asngari, P. S., \& Susanto, D. (2005). Persepsi Anak Jalanan Terhadap Bimbingan Sosial Melalui Rumah Singgah Di Kotamadya Bandung. Jurnal Penyuluhan, https://doi.org/10.25015/penyuluhan.v1i1.20 94 